\title{
Students' Perception on Perceived benefits of Online Social Interaction for Learning during COVID -19 Pandemic
}

\author{
Zuriadah Ismail, Anis Suriati Ahmad, Nor Nasriah Mohd Yadi \& Mohd Nazir \\ Zabit
}

To Link this Article: http://dx.doi.org/10.6007/IJARBSS/v12-i1/11889

DOI:10.6007/IJARBSS/v12-i1/11889

Received: 09 November 2021, Revised: 11 December 2021, Accepted: 29 December 2021

Published Online: 16 January 2022

In-Text Citation: (Ismail et al., 2022)

To Cite this Article: Ismail, Z., Ahmad, A. S., Yadi, N. N. M., \& Zabit, M. N. (2022). Students' Perception on Perceived benefits of Online Social Interaction for Learning during COVID -19 Pandemic. International Journal of Academic Research in Business and Social Sciences, 12(1), 762 - 772.

Copyright: (C) 2022 The Author(s)

Published by Human Resource Management Academic Research Society (www.hrmars.com)

This article is published under the Creative Commons Attribution (CC BY 4.0) license. Anyone may reproduce, distribute, translate and create derivative works of this article (for both commercial and non0-commercial purposes), subject to full attribution to the original publication and authors. The full terms of this license may be seen at: http://creativecommons.org/licences/by/4.0/legalcode

Vol. 12, No. 1, 2022, Pg. $762-772$

Full Terms \& Conditions of access and use can be found at http://hrmars.com/index.php/pages/detail/publication-ethics 


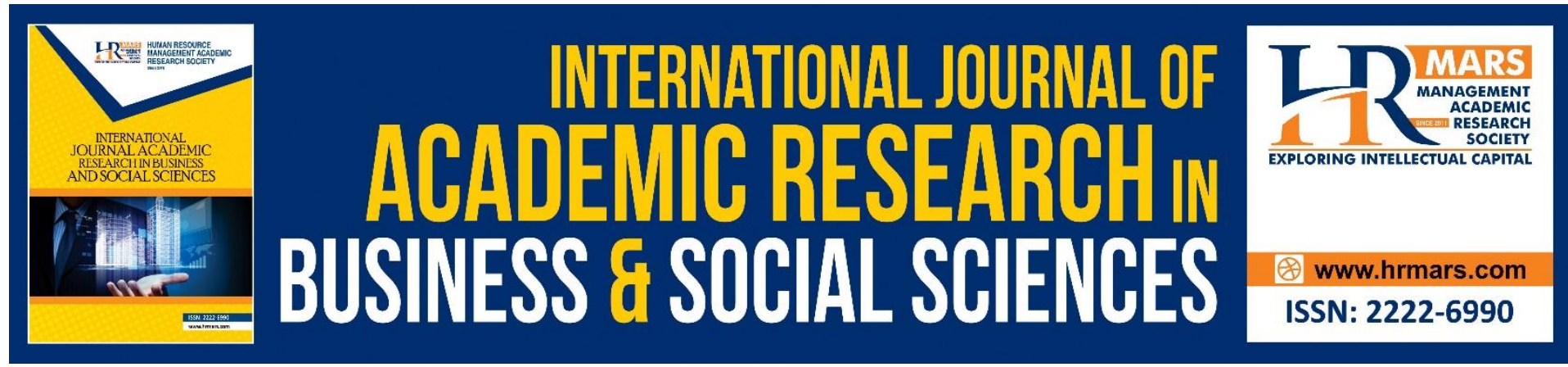

\title{
Students' Perception on Perceived benefits of Online Social Interaction for Learning during COVID -19 Pandemic
}

\author{
Zuriadah Ismail ${ }^{1}$, Anis Suriati Ahmad ${ }^{1}$, Nor Nasriah Mohd Yadi ${ }^{1}$ \\ \& Mohd Nazir Zabit ${ }^{2}$ \\ ${ }^{1}$ Faculty of Management and Economics, ${ }^{2}$ Faculty of Human Development, Universiti \\ Pendidikan Sultan Idris,35900 Tanjong Malim, Perak, Malaysia \\ Email: zuriadah@fpe.upsi.edu.my
}

\begin{abstract}
Due to the pandemic crisis, most of the classroom settings for various fields of education moves to an online learning environment with which most of the students and course instructors were not very familiar. This would affect on how their interact among each other. This study aims to determine the perceived benefits of online social interaction in online learning. This study uses descriptive statistics on the data collected from the accounting final year students who were learning online due to the pandemic COVID-19. The main results show that perceived benefits of online social interaction between students and the course instructor are more important than from fellow online students even though they have been experienced with online learning. This suggests that students are aware continuing learning online is more essential during a pandemic crisis. The study will be helpful for instructors to be more innovative in formulating online learning activities that can foster social interaction with fellow students in the online class and analyze their pedagogical approach to improve effectiveness.
\end{abstract}

Keywords: Perceived Benefits, Online Social Interaction, Pandemic Crisis

\section{Introduction}

The two years outbreak of Coronavirus Disease 2019 (COVID-19) experienced an effect on the way of teaching and learning delivery for most of the education providers where online classes are widely adopted in 120 countries (Azzi-Huck and Shmis, 2020). In Malaysia, to avoid disrupting the learning process, the government takes proactive action by implementing home-based teaching and learning (PdPR) classes. According to Tu and Corry (2002), three elements are important for online learning such as instruction, social interaction, and technology. While Saykili (018) indicates that implementing online learning requires for proper design and delivery approach. Further investigation for online learning definitions offers an explanation where some students associated with are a method of learning that offers new prospects in the classroom for various fields of education, (Rodrigues et al., 2019). While Shabha (2004) defined online learning as an e-learning method where a student can learn at any time or location over the Internet. So that, Researcher (2015) relates this learning 
process with Internet learning. Through this, interaction among students and between students and instructors is a crucial aspect to endure the student learning and understanding about courses. Responding the to above discussion, the study aims is

- to determine students' perception of the perceived benefits of social interaction in online learning.

\section{Related Literature Review}

Reviewing on literature proposed several concepts interaction in online learning. For example, in the study by Moore (1989); Su et al (2005); Abrami et al (2011); Alqurashi (2019), outlined the online learning interaction can take in place in many forms which is learnercontent interaction, learner- instructor interaction, and learner-learner interaction. While Baber (2020) relates interaction in online learning engaged with constructing a meaningful exchange of information and ideas where it is a psychosomatic perception toward the overall process between more than two people. In his study's discussion, it highlights about existing direction on enhancing interaction between instructors and learners (Saba, 2000; Shin and Chin, 2004; Woo and Reeves, 2007). Therefore, interaction during online learning is the key element for gaining learning experience and positive learning outcome (Kuo et al., 2014; Alqurashi, 2019). At the same, interaction leads to share values and interests (Tang and Tsui, 2018) and helps to build knowledge and empower learners (Holland, 2019).

For successful online learning, a hybrid learning experience is required according to Moore (1989). So, online learning interaction is a way for students to communicate outside of class by allowing them to obtain knowledge and improve skills in a different academic context. (Espitia et al., 2013). Kang and Im (2013) discovered that student-instructor interactions accounted for a large portion of both students' perceived learning and course satisfaction. In addition, Kim et al (2011) find that instructor interactions and student interactions predicted students' perceptions of social presence. However, students' active interaction does not occur automatically in online learning. So et al (2010) find that students' engagement in online learning was generally low when participation in online conversations, as compared of discussion boards. Other than that, Fung (2004) also emphasizes that online students participate in online learning to meet the requirement of their online instructors. So, the issue of social interaction has been observed to be less effective during online learning between students and instructors as equal as face-to-face interaction. In fact, the sudden shift toward online learning has raised concern to the failure of online instructors to use strategies to promote online interaction among students and between students and their instructors. This is consistent with Lee \& Choi (2011) find that learning in online classroom settings can be challenging to students because they might not feel comfortable interacting using online methods and asking questions or seeking assistance from online students even though they have experience with online learning (Cho \& Jonassen, 2009; Hrastinski, 2008). Therefore, some studies suggest that interaction the online learning needs to be facilitated by online instructors (An, Shin, \& Lim, 2009; Cho \& Kim, 2013; Hew, Cheung, \& Ng, 2010).

Despite the past studies suggesting the interaction is one of the critical success factors to support online learning and increase student learning outcome and satisfaction (Razali, Ahmad \& Noor, 2020), it also highlights the importan tindicators for interaction among the students (Alqurashi, 2019) and student with the instructor (Moon-Heum and Yoon-Jung, 2016). Therefore, Alqurashi (2019) includes the measure of socialization, instructor feedback, 
sharing and discussing ideas, group activities and content-related interaction that would improve student satisfaction of online learning. Similarly with Baber (2020) conducted a study and found interaction as the most important determinant of student perceived learning outcome and satisfaction in online learning during the COVID-19 pandemic. However, few studies find that interaction has also served an equally important element face to face learning (Kang and Im, 2013; Lasfeto, 2020).

Another related study in interactions of online learning by Rovai (2007) suggests the five strategies of social presence, learner-to-learner interaction, cultural communication patterns, gender-based communication patterns, and student status. Nonetheless, a lack of studies for defining and measuring all strategies had been explained by Moon-Heum and Yo-Jung (2016) to provide a useful scale for assessing the roles of strategies in promoting interactions in online learning contexts. Furthermore, the strategy of measuring social presence in online learning, the online instructor can use several proxies to evaluate online discussions such as the number of messages posting each day, maintaining focused discussions, and encouraging student dialogue by asking thought-provoking questions

According to Hirumi (2002), online learning interactions in some cases are not effectively achieved a social interaction among the students. Thus, Hwang and Song (2018) propose the adoption of learning theory in online learning to encourage interaction. Accordingly, the social interaction support for students may find in scaffolding theory by Lev Vygotsky. Moreover, their many effectiveness studies suggest a scaffolding approach contributes to active participation and builds common understanding through communicative exchanges (Stone, 1993). This implies that the student is not a passive participant during interaction with the instructor in an online class because interaction affects the learners' learning outcome (Mehall, 2020). A similar finding by Harasim et al (1995) indicates that social bonding has contributed to socio-affective and cognitive benefits for learning. In a later study by Neumann (1998) suggests an improvement of online learning through enhancing the interaction between students and instructors. Therefore, revisiting several past studies find that interaction between students and instructors increases the perceived better learning outcomes (Eom and Ashill, 2016; Baber, 2020). However, Eom et al (2006) find there is no empirical relationship between social interaction and perceived learning outcomes. Another study supports this finding by which social interaction has a negative influence on learners' perceived learning achievement in Korea by Kang and Im (2013). Among the reason, highlighted by Jung et al (2002) discovered that personal interaction such as social intimacy in the beginning and during the online course has a positive impact on the learners' learning outcome

\section{Research Methodology \\ Participants}

Final accounting students were chosen as the participants for this study from the Faculty of Management and Economics, Sultan Idris Education University which is having experience in online learning during the movement control order (MCO) period. The participants were 57 in the Semester 2 Session 2019/2020 (A192) and Semester 1 Session 2020/2021 (A201). Among them is mostly aged below 23 years old (89.5\%) and followed by those aged more than 23 years old $(10.5 \%)$ as the target participant. In terms of their enrollment background to the accounting program, the majority of the students were enrolled using Matriculation 
(75.4\%), Diploma (15.8\%), and followed by Malaysian Higher School Certificate (8.8\%). Around $19.3 \%$ of participants were male and the rest were female $(80.7 \%)$ as shown in Table 1.

Table 1 - Demographic classification

\begin{tabular}{llll}
\hline Demographic & Classification & Frequency & Percent (\%) \\
\hline Age & Below 23 years old & 51 & 89.5 \\
Gender & Above 23 years old & 6 & 10.5 \\
& Male & 11 & 19.3 \\
Enrolment & Female & 46 & 80.7 \\
& Matriculation & 43 & 75.4 \\
& Malaysian Higher & 5 & 8.8 \\
& School Certificate & \\
\multirow{4}{*}{ Program } & (STPM) & & \\
& Diploma & 9 & 15.8 \\
& AT08 & 35 & 61.4 \\
& AE02 & 22 & 38.6 \\
\hline
\end{tabular}

\section{Instruments}

A structured questionnaire was designed according to past literature surveys such as Cho and Cho (2016) and Christopoulos, Conrad \& Mitul (2014). For designing the final questionnaire, the pre-testing was conducted with 30 participants and their feedback was considered. The questionnaire in this study included twenty items for perceived benefits in online learning interaction that were applied to scale. The reliability of the full survey for social interaction in online learning between student and student was 0.955 , and 0.929 for student and instructor.

\section{Data Analysis and Discussions}

The data were analyzed using descriptive statistics as the study focuses on determining students' perception towards perceived benefits of social interaction in online learning among the final year accounting students. The findings are organized by research objectives. Table 2 provides data on students' perceptions toward the perceived benefits of social interaction between students and students in online learning. The students were asked to respond to ten statements regarding their experience in online class interaction. The table displays the mean values of students' agreement with the statements regarding their perceived benefits of social interaction in online learning. Based on the overall mean value (3.99), it shows that the student agrees with the presence of advantages for social interaction in their online learning such as encouraging them to share knowledge (4.26), collaboration (4.18), positive thinking (4.14), and sharing common goal (4.07) and encourage participation (4.05). In term of the contribution of social interaction in online learning, it also help the student to receive real-time feedback from their fellow students (3.96), make learning materials more attractive (3.96), interactive communication (3.84), make their learning easy (3.79) and fun (3.61). 
Table 2:Students' perception of perceived benefits of social interaction in online learning between students and fellow online students.

\begin{tabular}{|c|c|c|c|}
\hline Perceived Benefits & $\mathbf{N}$ & Mean & $\begin{array}{l}\text { Std. } \\
\text { Deviation }\end{array}$ \\
\hline $\begin{array}{l}\text { Interaction in online learning encourage knowledge } \\
\text { sharing }\end{array}$ & 57 & 4.26 & 1.126 \\
\hline Interaction in online learning encourages collaboration & 57 & 4.18 & 1.283 \\
\hline $\begin{array}{l}\text { Interaction in online learning encourages a positive } \\
\text { thinking }\end{array}$ & 57 & 4.14 & 1.342 \\
\hline $\begin{array}{l}\text { Interaction in online learning encourages students to } \\
\text { share a common goal. }\end{array}$ & 57 & 4.07 & 1.147 \\
\hline Interaction in online learning encourages participation & 57 & 4.05 & 1.274 \\
\hline $\begin{array}{l}\text { Interaction in online learning encourages students to } \\
\text { provide and receive real-time feedback }\end{array}$ & 57 & 3.96 & 1.322 \\
\hline $\begin{array}{l}\text { Interaction in online learning encourages students to } \\
\text { share attractive learning materials. }\end{array}$ & 57 & 3.96 & 1.267 \\
\hline $\begin{array}{l}\text { Interaction in online learning encourages students to } \\
\text { communicate in interactively. }\end{array}$ & 57 & 3.84 & 1.373 \\
\hline Interaction in online learning made the learning easier & 57 & 3.79 & 1.473 \\
\hline Interaction in online learning made the learning fun & 57 & 3.61 & 1.461 \\
\hline Overall mean & & 3.99 & \\
\hline
\end{tabular}

Then, the students were asked to respond to ten statements in regards to the perceived benefits of social interaction in online learning between students and instructors. Table 3 illustrates the mean values of students who agree to the statements based on their perceptions of the perceived benefits of social interaction in online learning. Based on the average mean value (4.69), students in this study strongly agree that interaction in online learning provides positive benefits to them. The result shows that the students agree that the presence of social interaction in their online learning encourages the instructor to provide a quick response (4.89), monitors students collaboration with others and encourage active participation (4.86), provide regular feedback (4.70), and ask questions (4.68), provide positive and supportive comments (4.67) and guidelines (4.65), actively participate (4.54), encourages students to share their problems (4.53) and monitor students interaction (4.51). 
Table 3: Students' perception of perceived benefits of social interaction in online learning between students and course instructor.

\begin{tabular}{|c|c|c|c|}
\hline Perceived Benefits & $\mathbf{N}$ & Mean & $\begin{array}{l}\text { Std. } \\
\text { Deviation }\end{array}$ \\
\hline $\begin{array}{l}\text { In online learning, the instructor promptly responds to } \\
\text { students' requests. }\end{array}$ & 57 & 4.89 & 0.920 \\
\hline $\begin{array}{l}\text { In online learning, the instructor monitors group } \\
\text { collaboration }\end{array}$ & 57 & 4.86 & 0.934 \\
\hline $\begin{array}{l}\text { In online learning, If students 'interaction is low, the } \\
\text { students encourage students to participate actively in } \\
\text { interaction by sending a note }\end{array}$ & 57 & 4.86 & 0.854 \\
\hline $\begin{array}{l}\text { In online learning, the instructor provides regular } \\
\text { feedback on student interactions. }\end{array}$ & 57 & 4.70 & 0.963 \\
\hline $\begin{array}{l}\text { In online learning, the instructor encourages students to } \\
\text { ask questions. }\end{array}$ & 57 & 4.68 & 1.003 \\
\hline $\begin{array}{l}\text { In online learning, the instructor provides positive and } \\
\text { supportive comments to encourage students to } \\
\text { continue participating in online interactions. } \\
\text { In online learning, the instructor provides guideline to }\end{array}$ & 57 & 4.67 & 1.024 \\
\hline $\begin{array}{l}\text { assist students to become aware of the importance of } \\
\text { online interaction }\end{array}$ & 57 & 4.65 & 0.935 \\
\hline $\begin{array}{l}\text { In online learning, the instructor actively participates in } \\
\text { online discussion by replying, summarizing the } \\
\text { discussion, and asking questions to students }\end{array}$ & 57 & 4.54 & 0.946 \\
\hline $\begin{array}{l}\text { In online learning, the instructor encourages students to } \\
\text { share their problems. }\end{array}$ & 57 & 4.53 & 0.908 \\
\hline $\begin{array}{l}\text { In online learning, the instructor monitors how the } \\
\text { student interacts with each other. }\end{array}$ & 57 & 4.51 & 1.088 \\
\hline Overall mean value & & 4.69 & \\
\hline
\end{tabular}

Based on the study's results, it shows that social interaction between students and instructors was ranked higher than interaction among the students in online learning. This suggests that the student perceived more satisfied to interact with $\mathrm{h}$ course instructor online as the students are aware of the presence of social interaction in their online classes. The result is somewhat consistent with findings by (Harasim et.al., 1995), Kang and Im., 2013; Kuo et al., 2014; Alqurashi, 2019). All studies provide evidence that shows a social interaction during online learning is the crucial element for gaining positive learning outcomes. Also, studentinstructor interactions accounted for a large portion of both students' perceived learning and course satisfaction. And among the indicating reason is that social bonding influences and cognitive benefits for learning. The students chose online learning as a medium of their interaction the with course instructor due to quick response and effective monitoring. Other than that, the course instructor is always encouraged the student to actively participate and receive regular and positive feedback and guidelines through sharing problems and monitoring students' interaction. This would them to work at their own pace. As a consequence, Alqurashi (2019) includes the element of socialization, instructor feedback, sharing and discussing ideas, group activities, and content-related interaction in order to 
improve student satisfaction with online learning. This implies that the student-course instructor is not a passive participant during interaction it would affect the students' learning outcome (Mehall, 2020).

Although many studies identified that online learning provides advantages as equal to offline learning. However, in terms social interaction produces different results. For example, Eom et al (2006); Kang and Im (2013) emphasized no empirical association between social interaction and learning outcomes. Whilst, Hew, Cheung \& Ng, (2010) find that students' participation was exceedingly low when in online conversations. Therefore, course instructors would experience a challenging task, particularly in online classroom settings according to Lee \& Choi (2011). The student might not feel comfortable interacting by way of online methods, or asking questions or seeking assistance from fellow online students even though they have experience with online learning. This could be dedicated to the study result where the mean value of interaction among the students in online learning is relatively low (Cho \& Jonassen, 2009; Hrastinski, 2008).

\section{Conclusion}

Whilst online learning has turned out to be a popular approach during the pandemic crisis, but it was sudden and not fully planned. These results for a study focus to determine the effectiveness of online learning to promote social interaction among the students and their course instructor. In specific, the study attempts to examine the students' perception of perceived benefits of social interaction in online learning as students are feeling socially isolated during the MCO. The study found that the students agree with the presence of an advantage for social interaction in their online learning, however, social interaction between student and course instructor was ranked higher than interaction among the fellow students. The result suggests that students perceive that social interaction with their instructor is more important for online learning when they are aware continuing learning online is more essential. As the study participants are selected among the final accounting students, so future research can focus on examining the study programs and various activities which can improve interaction in the online learning environment. From the side of course Instructors need to be innovative online learning activities that can foster students' interaction with fellow students in the online class.

\section{Acknowledgement}

This research is supported by the Research Management Centre of the Universiti Pendidikan Sultan Idris under the University Short-Term Grants (GPU- 2020-0111-107-01)

\section{References}

Abrami, P. C., Bernard, R. M., Bures, E. M., Borokhovski, E., \& Tamim, R. M. (2011). Interaction in distance education and online learning: Using evidence and theory to improve practice. Journal of Computing in Higher Education, 23(2-3), 82-103. Retrieved from https://doi.org/10.1007/s12528-011-9043-x

Alqurashi, E. (2019). Predicting student satisfaction and perceived learning within online learning environments. Distance Education, 40(1), 133-148. Retrieved from https://doi.org/10.1080/01587919.2018.1553562

An, H., Shin, S., \& Lim, K. (2009). The effects of different instructor facilitation 
approaches on students' interactions during asynchronous online discussions. Computer \& Education, 53(3), 749-760. Retrieved from

https://www.academia.edu/4692855/The_effects_of_different_instructor_facilitation _approaches_on_students_interactions_during_asynchronous_online_discussions

Azzi-Huck, K., and Shmis, T. (2020). Managing the impact of COVID-19 on education systems around the world: How countries are preparing, coping, and planning for recovery. Retrieved from https://blogs.worldbank.org/education/managing-impactcovid-19-education-systems-around-world-how-countries-are-preparing

Baber, H. (2020). Determinants of students' perceived learning outcome and satisfaction in online learning during the pandemic of Covid19. Journal of Education and e-Learning Research, 7(3), 285-292. Retrieved from https://www.asianonlinejournals.com/index.php/JEELR/article/view/2048/1598

Baber, H. (2020). Social Interaction and effectiveness of the online learning - A moderating role of maintaining social distance during the pandemic COVID-19. Asian Education and Development Studies. Retrieved from https://doi.org/10.1108/AEDS-092020-0209

Cho, H. M., \& Cho, J. Y. (2016). Online Instructors' Use of Scaffolding Strategies to Promote Interactions: A Scale Development Study. International Review of Research in Open and Distributed Learning,17(6). Retrieved from https://doi.org/10.19173/irrodl.v17i6.2816

Cho, M.-H., \& Jonassen, D. (2009). Development of the human interaction dimension of the self-regulated learning questionnaire in asynchronous online learning environments. Educational Psychology, 29(1), 117-138. Retrieved from https://www.learntechlib.org/p/70774/

Cho, M.-H., \& Kim, B. J. (2013). Students' self-regulation for interaction with others in online learning environments. Internet and Higher Education, 17, 69-75. Retrieved from https://doi.org/10.1016/j.iheduc.2012.11.001

Christopoulos, A., Conrad, M., \& Shukla,M. (2014). Object, Worlds and Students: Virtual Interaction in Education. Education Research International, 1-20. Retrieved from https://doi.org/10.1155/2014/318317

Eom, S. B., and Ashill, N. (2016), "The determinants of students' perceived learning outcomes and satisfaction in university online education: an update", Decision Sciences Journal of Innovative Education, 14(2), 185-215. Retrieved from https://doi.org/10.1111/dsji.12097

Eom, S. B., Wen, H. J., and Ashill, N. (2006), "The determinants of students' perceived learning outcomes and satisfaction in university online education: an empirical investigation", Decision Sciences Journal of Innovative Education, 4(2,) 215-235. Retrieved from https://doi.org/10.1111/j.1540-4609.2006.00114.x

Espitia, M., \& Cruz, C. (2013). Peer-feedback and online interaction: a case study. íkala, revista de lenguaje y cultura, 18(2), 131-151. Retrieved from http://www.scielo.org.co/scielo.php?script=sci_arttext\&pid=S012334322013000200009

Fung, Y. Y. H. (2004). Collaborative online learning: Interaction patterns and limiting factors. Open Learning: The Journal of Open, Distance and e-Learning, 19(2), 135-149. Retrieved from https://doi.org/10.1080/0268051042000224743

Harasim, L. M., Hiltz, S. R., Teles, L., and Turoff, M. (1995), Learning Networks: A Field Guide to Teaching and Learning Online, MIT press, Cambridge, MA. 
Hew, K. F., Cheung, W. S., \& Ng C. S. L. (2010). Student contribution in asynchronous online discussion: a review of the research and empirical exploration. Instructional Science, 38(6), 571-606. Retrieved from https://www.jstor.org/stable/23372901

Hirumi, A. (2002), "A framework for analyzing, designing, and sequencing planned e-learning interactions", Quarterly Review of Distance Education, 3(2), 141-160.

Holland, A.A. (2019), "Effective principles of informal online learning design: a theory-building metasynthesis of qualitative research". Computers and Education, 128(1), 214-226. Retrieved from https://www.learntechlib.org/p/201615/

Hrastinski, S. (2008). What is online learner participation? A literature review. Computers \& Education, 51(4), 1755-1765. Retrieved from https://www.learntechlib.org/p/66417/

Hwang, S., and Song, H. (2018), "Effective social interaction in online learning", National Teacher Education Journal, 11(3) 41-46.

Jung, I., Choi, S., Lim, C., and Leem, J. (2002), "Effects of different types of interaction on learning achievement, satisfaction and participation in web-based instruction", Innovations in Education and Teaching International, 39(2), 153-162. Retrieved from https://www.learntechlib.org/p/93814/

Kang, M., \& Im, T. (2013). Factors of learner-instructor interaction which predict perceived learning outcomes in online learning environment. Journal of Computer Assisted Learning, 29(3), 292-301. Retrieved from https://doi.org/10.1111/jcal.12005

Kim, J., Kwon, Y., \& Cho, D. (2011). Investigating factors that influence social presence and learning outcomes in distance higher education. Computers \& Education, 57(2), 1512-1520. Retrieved from https://www.learntechlib.org/p/50774/

Kuo, Y. C., Walker, A. E., Schroder, K. E., and Belland, B. R. (2014), "Interaction, Internet self-efficacy, and self-regulated learning as predictors of student satisfaction in online education courses", The Internet and Higher Education, 20, 35-50. Retrieved from https://doi.org/10.1016/j.iheduc.2013.10.001

Lasfeto, D. (2020), "The relationship between self-directed learning and students' social interaction in online learning environment", Journal of E-Learning and Knowledge Society, 16(2), 34-41. Retrieved from https://doi.org/10.20368/1971-8829/1135078

Lee, Y., \& Choi, J. (2011). A review of online course dropout research: implications for practice and future research. Educational Technology Research and Development, 59, 593-618. Retrieved from https://www.learntechlib.org/p/50902/

Mehall, S. (2020). Purposeful interpersonal interaction in online learning: what is it and how is it measured?, Online Learning, 24(1),182-204. Retrieved from https://files.eric.ed.gov/fulltext/EJ1249281.pdf

Moore, M. G. (1989). Editorial: Three types of interaction. American Journal Distance Education,3(2), 1-7. Retrieved from https://doi.org/10.1080/08923648909526659

Neumann, P. G. (1998), "Risks of e-education", Communications of the ACM, 41(10), 136-137. Retrieved from https://doi.org/10.1145/286238.286255

Razali, S. N., Ahmad, M. H., and Noor, H. A. M. (2020), "Implications of learning interaction in online project based collaborative learning", Journal of Computational and Theoretical Nanoscience, 17(2-3), 681-688. Retrieved from https://www.researchgate.net/publication/341042650_Implications_of_Learning_Inte raction_in_Online_Project_Based_Collaborative_Learning 
Riahi, G. (2015). E-learning systems based on Cloud computing: A review. Procedia Computer Science, 62, 352-359. Retrieved from https://doi.org/10.1016/j.procs.2015.08.415

Rodrigues, H., Almeida, F., Figueiredo, V., \& Lopes, S. L. (2019). Tracking e-learning through published papers: A systematic review. Computers \& Education, 136, 87-98. Retrieved from https://doi.org/10.1016/j.compedu.2019.03.007

Rovai, A. P. (2007). Facilitating online discussions effectively. Internet and Higher Education, 10(1), 77-88. Retrieved from https://doi.org/10.1016/j.iheduc.2006.10.001

Saba, F. (2000). Research in Distance Education: A Status Report. The International Review of Research in Open and Distributed Learning, 1(1), 1-9. Retrieved from http://www.irrodl.org/index.php/irrodl/article/view/4/24

Saykılı, A. (2018). Distance education: Definitions, generations, key concepts and future directions. International Journal of Contemporary Educational Research, 5(1), 217.Retrieved from https://files.eric.ed.gov/fulltext/EJ1207516.pdf

Shabha, G. (2004). An assessment of the effectiveness of e-learning on university space planning and design. Facilities,22(3/4), 79-86. Retrieved from https://doi.org/10.1108/02632770410527815

Shin, N., and Chan, J. K. (2004), "Direct and indirect effects of online learning on distance education",British Journal of Educational Technology, 35(3), 275-288. Retrieved from https://numerons.files.wordpress.com/2012/04/25direct-and-indirecteffects-of-online-learning.pdf

Stone, C. A. (1998). "The Metaphor of Scaffolding: Its Utility for the Field of Learning Disabilities." Journal of Learning Disabilities 31 (4): 344-364. Retrieved from https://citeseerx.ist.psu.edu/viewdoc/download?doi=10.1.1.825.9460\&rep=rep1\&typ $\mathrm{e}=\mathrm{pdf}$

Su, B., Bonk, C. J., Magjuka, R. J., Liu, X., \& Lee, S. (2005). The importance of interaction in web-based education: A program-level case study of online MBA courses. Journal of Interactive Online Learning, 4(1), 1-19. Retrieved from https://www.ncolr.org/jiol/issues/pdf/4.1.1.pdf

Tang, H. H. H., and Tsui, C. P. G. (2018), "Democratizing higher education through internationalization: the case of HKU SPACE". Asian Education and Development Studies, 7(1), 26-41. Retrieved from https://doi.org/10.1108/AEDS-12-2016-0095

Tu, C. H., \& Corry, M. (2002). Research in online learning community. E-Journal of Instructional Science and Technology, 5(1),1-11. Retrieved from https://www.researchgate.net/publication/26392290_RESEARCH_IN_ONLINE_LEARNI NG_COMMUNITY

Woo, Y., and Reeves, T. C. (2007), "Meaningful interaction in web-based learning: a social constructivist interpretation", The Internet and Higher Education, 10(1), 15-25. Retrieved from https://doi.org/10.1016/j.iheduc.2006.10.005 